\title{
シャント静脈表在化症例の検討
}

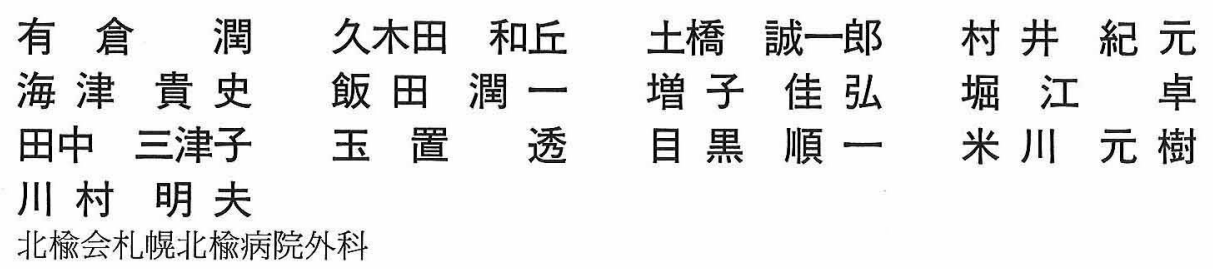

key words：シャント静脈表在化，ブラッドアクセス

〈要旨〉

高齢者, 糖尿病合併透析患者が増加傾向にあり，皮静脈での内シャント作成が困難な症例も少なくない。 また内 シャント作成が成功しても，深部を走行し，穿刺が困難な症例もある.このような深部シャント静脈を利用するた めに，われわれはシャント静脈の表在化を行ってきた.

1991 年から 2000 年までの 10 年間で, 当院で施行した全シャント症例 1610 例中, $1.4 \%$ にたる 23 例を対象とし た. 表在化の理由は, 穿刺困難 18 例, 返血困難 3 例, シャント発達不良 2 例であった. 2 週間以内に穿刺可能であっ た症例を一次成功例としたが，それは 19 例（82.6\%）であった。 それらのうちシャント造影を施行した症例では， いずれも直径が $6 \mathrm{~mm}$ 以上あった，血栓により閉塞した症例はシャント吻合部に狭窄を認めた，一方，一次不成功 例のシャント造影では 3 4 mm とシャント静脈自体が細く，また周囲組織による圧迫もあり発達不良であった.

Kaplan-Meier 法による一次開存率は，1 年 65.2\%，3 年 48.9\%，5 年 36.7\%，また二次開存率は 1 年 $71.2 \% ， 3$ 年 $55.4 \%, 5$ 年 $41.5 \%$ であり，術前の造影検査で症例を絞れば，人工血管移植例と遜色のない有用なブラッドアク セスと思われる.

表在化した静脈は，とれ自体の太さ，周囲組織による圧迫や，狭窄によるシャント発達不良などで使用できない こともある. 表在化静脈の直径が一定以上すなわち，シャント造影で $6 \mathrm{~mm}$ 以上の径があれば，術後の開存が可能 と考えられ，定期的な造影検査を行い，経皮的血管形成術（PTA）などを施行することにより長期的開存も期待で きる.

\section{The patency of superficialized shunt vein for blood access}

Jun Arikura, Kazutaka Kukita, Seiichiro Tsuchihashi, Noriyuki Murai, Takashi Kaizu, Junichi lida, Yoshihiro Masuko, Takashi Horie, Mitsuko Tanaka, Toru Tamaki, Junichi Meguro, Motoki Yonekawa, Akio Kawamura

Sapporo Hokuyu Hospital, Research Institute for Artificial Organs

The number of older and diabetic-related hemodialysis patients are increasing. It is sometimes difficult to establish an arterial-venous (AV) fistula in such patients. Therefore, we have established a shunt vein access at a superficial level to achieve an easier puncture. We used this technique in 23 patients between 1991 and 2000. In successful cases, we could puncture the new blood access in two weeks. In these cases, the vein size was over $6 \mathrm{~mm}$ in diameter on angiography. In unsuccessful cases, vein diameter was under $4 \mathrm{~mm}$. Patency was lost in three of the previously successful cases because of stenosis near the anastomosis. The primary patency rates of AV-fistula with superficialized vein are $65.2 \%$ after 1 year, $48.9 \%$ after 3 years and $36.7 \%$ after 5 years and secondary patency rates are $71.2 \%, 55.4 \%$ and $41.5 \%$ respectively by Kaplan-Meier analysis. The superficialized shunt vein as well as the artificially grafted vessels are useful for blood access. However, because of narrowing veins and scarring of surrounding tissue, the superficialized shunt vein cannot be expanded to

有倉 潤 現 旭川医科大学第 2 外科 $\overline{\mathrm{T}}$ 078-8510 旭川市緑ヶ丘東 2 条 1-1-1

Jun Arikura Tel :0166-68-2503 Fax :0166-68-2193

〔受付：平成 13 年 8 月 10 日, 受理 : 平成 13 年 10 月 26 日〕 
puncture for blood access. We conclude that the superficialized shunt vein is useful for blood access in cases whose shunt veins are over $6 \mathrm{~mm}$ in diameter. It is sometimes necessary to evaluate the superficialized veins by angiography, and when stenosis is diagnosed, PTA can be applied for long-term blood access.

\section{緒言}

最近，高齢者，糖尿病合併透析患者が増加傾向にあ り，皮静脈での内シャント作成が困難な症例も少なく ない. また内シャント作成が成功しても，シャント静 脈が深部を走行し，穿刺が困難な症例もある。このよ うなシャント静脈を利用するために，われわれはその 表在化を行ってきた。表在化シャント静脈の開存成績 の報告は少ないため, それらの転帰について検討し報 告する.

\section{I . 対象と方法}

\section{1. 対 象}

1991 年から 2000 年までの 10 年間で, 当院で施行し た全シャント症例 1610 例中, $1.4 \%$ にあたる 23 例を対 象とした。表在化の理由は, 穿刺困難 18 例, 返血困難 3 例，シャント発達不良 2 例であった。

年齢は 5 歳から 81 歳, 平均 62.3 歳. 性別は男性 7 名, 女性 16 名. 基礎疾患は, 慢性系球体腎炎 16 例, 糖尿病 5 例, 妊娠中毒症 1 例, Wilms 腫瘍 1 例であっ た。透析歴は 1 年までが 7 名 $(30.4 \%) ， 5$ 年までが 14 名 $(60.9 \%)$ と比較的早期に多かった. 一方 15 年以上 の長期透析患者も 3 名 (13.0\%) みられた。 ブラッド アクセス回数では，1，2 回の症例が 13 例 (56.5\%) と 半数を占め, 3 回 2 例, 4 回 3 例, 5 回 1 例であった.
6 回以上は 3 例であった。

\section{2. 方 法}

以上の患者を対象に, 内シャントは開存しているも, 表在静脈の穿刺が困難な症例に対し，シャント静脈を 表在化した，有効であった内シャント作成から静脈表 在化までの期間は, 1 か力以内が 8 例, 1 年以内では 15 例で, 最長 17 年であった。

a）シャント静脈の表在化法：上腕で静脈表在化予 定部位より約 $1 \mathrm{~cm}$ 離し，いずれも約 $10 \mathrm{~cm}$ の縦切開 の皮切を抢く，皮下脂肪組織を割り，上腕二頭筋膜を 切開し静脈を露出する。シャント静脈の表在化に使用 する血管は，上腕の未梢側 $1 / 3$ から筋膜下を走行し， 良好な状態で温存されている尺側皮静脈を主に使用し ている，また，深部上腕静脈を利用する場合もある。 いずれの場合も穿刺部位を長くとるため上腕二頭筋膜 を切開している，表在化する静脈をできるだけ長く剥 離し，上腕二頭筋膜，皮下脂肪層より前面にもちあげ る。表在化する部位は皮切部より離し，㓔痕による圧 迫がなく，第刺の妨げにならないようにしている（図 1).

b ）開存率：Kaplan-Meier 法により累積開存率を 求めた。

\section{II. 結 果}

浮腫があってもほほ消失する 2 週間以内に穿刺可能 であった症例を一次成功例としたが，それは 19 例

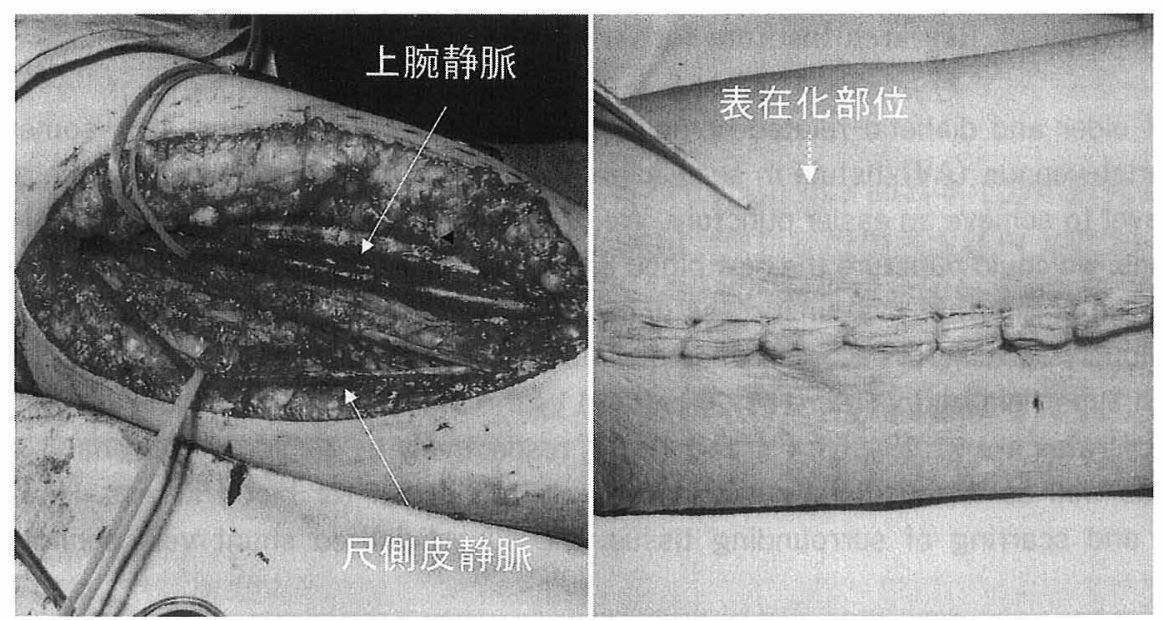

図 1 シャント静脈の表在化，上腕に約 $10 \mathrm{~cm}$ の縦切開の皮切をおく．主に尺 側皮静脈を使用している。表在化する部位は皮切部より離し，疫痕によ る圧迫がなく，穿刺の妨げにならないようにしている。(…・) 

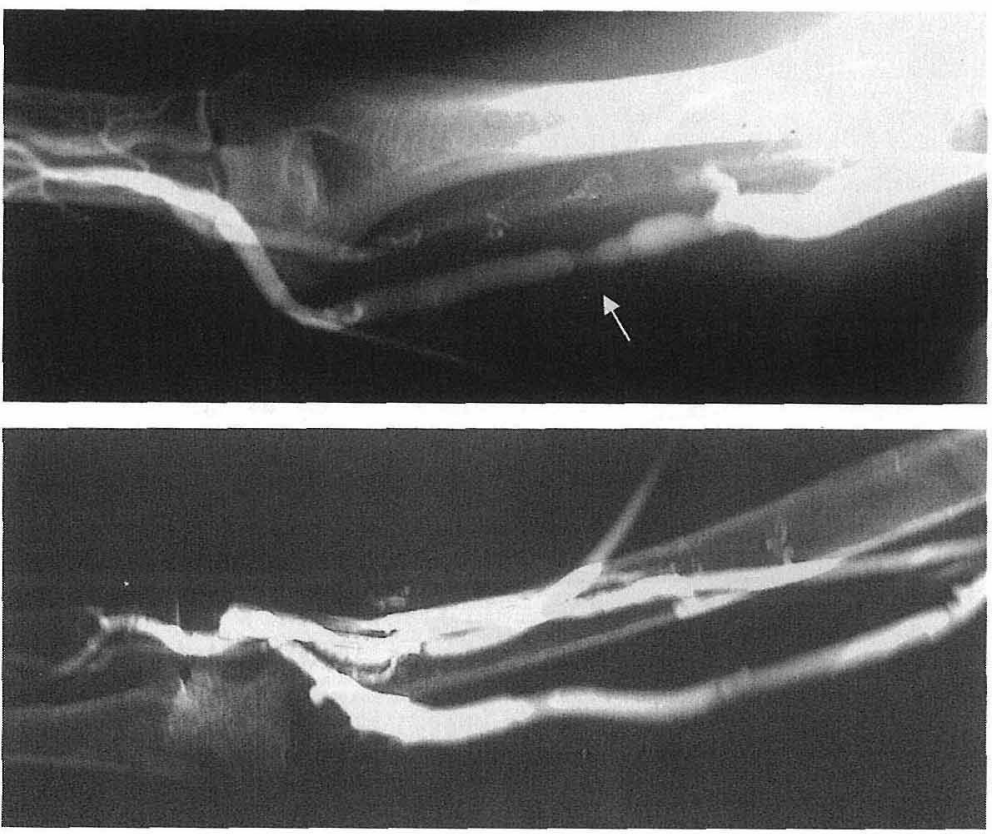

図 2 一次成功例

上（症例 1)：径：6〜8 mm， 尺側皮静脈を表在化したが一部に狭窄あり（๘） PTA にて長期開存中.

下（症例 2)：径：6〜8 mm， 尺側皮静脈を表在化.
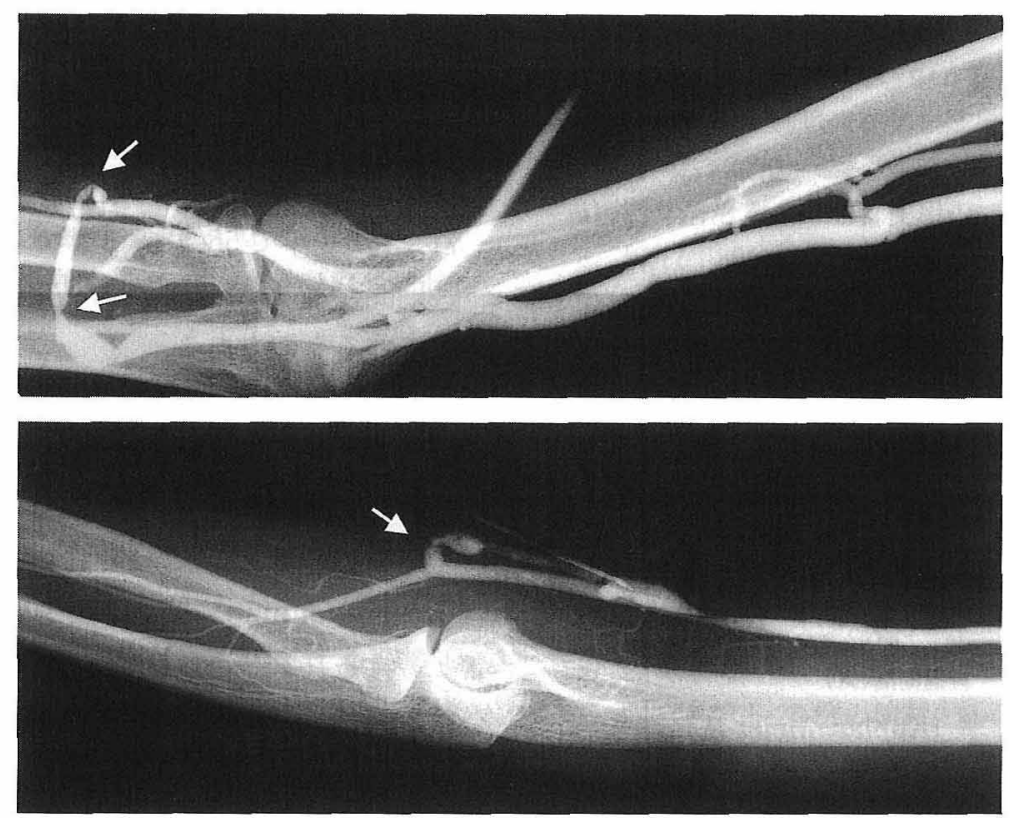

図 3 一次成功後の閉塞症例

上（症例 3)：内シャント表在静脈径：7〜 $8 \mathrm{~mm}$. 下（症例 4)：内シャント表在 静脈径：6〜 $7 \mathrm{~mm} ，$ いずれも，内シャント吻合部近辺に狭窄を認めた。（ヶ）

(82.6\%)であった.それらのうちシャント造影を施行 した症例は 8 例で, 術前造影 7 例, 術後造影 1 例であ る、いずれも直径が $6 \mathrm{~mm}$ 以上あった（図 2 , 症例 1 , 2). 症例 1 は狭窄部を認めたが, 定期的な造影および, PTAにより 38 か月開存中である，症例 2 は尺側皮静 脈を表在化し，問題なく穿刺可能となった。一次成功 例のなかで, 5 例は後に閉塞し, そのうち 3 例は血栓に
よる閉塞が原因であった，血栓除去後に造影した 2 例 ではいずれも直径が $6 \mathrm{~mm}$ 以上あったが，シャント吻 合部近辺に狭窄を認めていた（図 3, 症例 3，4）.

一次不成功例は 4 例で，原因は表在化静脈に狭窄が あったもの 1 例, 元の静脈が細く, シャント発達不良 であったもの 1 例, 瘢痕など周囲組織による圧迫が あったもの 2 例であった，症例 5 は 57 歳女性, 基礎疾 

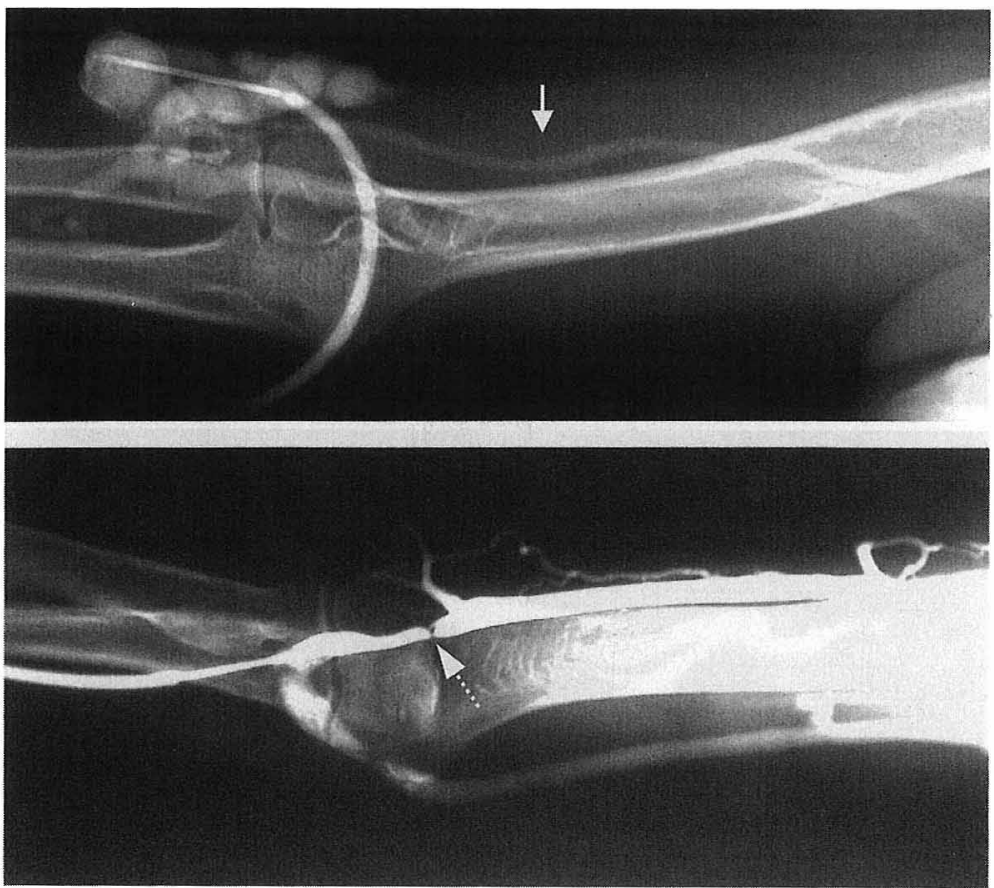

図 4 一次不成功例

上 (症例 6)：表在化静脈径：3〜 4 mm，シャント静脈自体が細く, 周囲組織に よる圧迫を認めた。( (

下 (症例 7)：表在化静脈径 : $6 \mathrm{~mm}$, 表在化後の造影で狭窄を認め, 血流不良で あった.（…・)

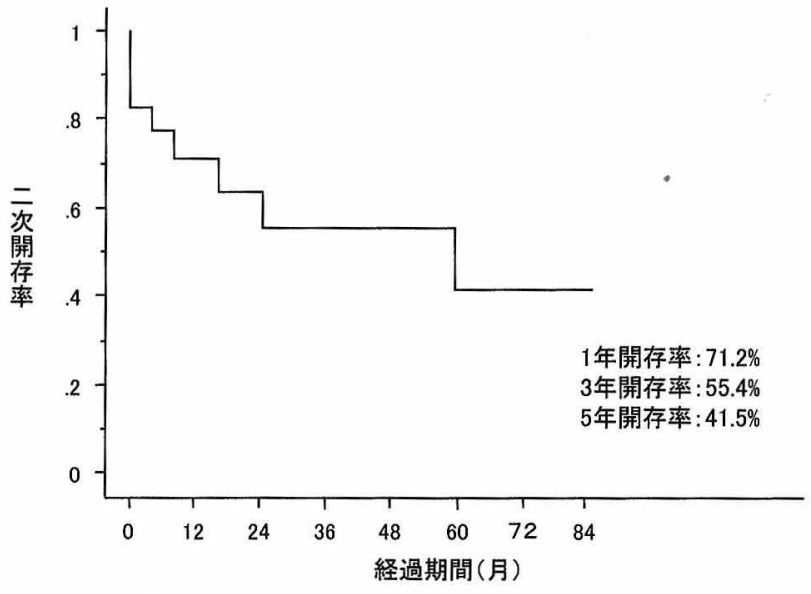

図 5 二次開存率 (Kaplan-Meier 法)

患は慢性系球体腎炎である。穿刺困難によりシャント 静脈を表在化したが，シャント造影では $3 〜 4 \mathrm{~mm}$ と シャント静脈自体が細く，また，周囲組織による圧迫 もあり発達不良であった（図 4 上）.

症例 6 は 62 歳女性で, 基礎疾患は糖尿病性腎症であ る. 返血困難により，表在化した。シャント造影では $6 \mathrm{~mm}$ あったが, 表在化後の造影で静脈の一部に狭窄 を認めていた，PTAによる拡張を急ぐべき症例で あった（図 4 下).

Kaplan-Meier 法による一次開存率は, 1 年 $65.2 \%$,
3 年 $48.9 \%, 5$ 年 $36.7 \%$ であり，血栓除去あるいは狭 窄部に対するPTA を施行した二次開存率は，1年で $71.2 \%, 3$ 年で $55.4 \%, 5$ 年で $41.5 \%$ であった (図 5 ). 長期開存例では， 60 か月， 70 か月，最長 84 か月開存 しているものもある.

\section{III. 考 察}

血液透析患者にとって良いブラッドアクセスは, Brescia-Cimino らの方法を原則とした内シャント と考えられる.しかし, 最近, 患者背景からも高齢者, 糖尿病合併透析患者が増えてきており，また，透析の 長期化により，自家表在皮静脈での内シャント作成が 困難な症例や，シャント静脈の発達が悪かったり，透 析患者の内シャント作成が成功しても，穿刺が困難な 症例もある。このような場合，一般には上腕動脈表在 化, 人工血管移植, パーマネントカテーテル留置など が施行されているが, 動脈瘤の形成, 破裂や感染など の問題がある ${ }^{2 \sim 5)}$. そこで，われわれは，せっかく作成 した时部内シャントを利用するために，上腕でシャン 卜静脈の表在化を施行した。

表在化したシャント静脈を 2 週間以内に穿刺できた 症例は,シャント造影を施行した 8 例で検討した結果, いずれも直径 $6 \mathrm{~mm}$ 以上の血管径であった，一方，穿 
刺困難であった 4 例の血管径は 3〜 $4 \mathrm{~mm}$ と細かっ た。ささに，周囲組織による圧迫も加わったことが原 因で一次不成功になったものと考えられた，今回の検 討では症例数が少ないが, 臨床的には静脈径が $6 \mathrm{~mm}$ 以上あれば使用可能と考えられ，4 $\mathrm{mm}$ 以下では使用 できない可能性が高いと思われる。

表在化した静脈が狭窄を生じないよう長く剥離し， 緊張がかからないようにしたが，表在化静脈が使用途 中で血栓による閉塞をきたした症例 3,4では, シャン 卜造影を見直したところ，吻合部近辺の狭窄を認めて いた，一方，術前より静脈に狭窄を認めていたが，定 期的な造影により，狭窄部を PTA で拡張できた症例 1 は 38 か月と長期開存中であることから, 術前にシャ ント造影を施行し，吻合部狭窄や静脈の狭窄を認める 症例は，吻合部の再吻合やPTAによる拡張が必要と 思われた。

Kaplan-Meier 法による累積開存率は，1年で $71.2 \% ， 3$ 年で $55.4 \% ， 5$ 年で $41.5 \%$ あ゙あた。松尾 $ら^{3)}$ による, 表在化動脈の機能的一次開存率は，1年 で $92.9 \%, 3$ 年で $86.0 \%, 5$ 年で $70.9 \%$ となっており， また、ゴアテックス人工血管の開存率は，1年 $68 \sim 88 \% ， 3$ 年約 $50 \% ， 5$ 年 $33 \sim 45 \%$ と報告されてい る4,6,7). したがって人工血管とほほ同等の開存率であ るが, 動脈表在化よりは劣る。しかし, 術前造影検査 で静脈表在化適応症例を絞り，PTAなどによる狭窄 部の拡張を図ることで，さらなる開存率の向上が期待 される。

動静脈の表在化の合併症として, 術後のリンパ液瘦, 浮腫による創傷治癒遅延, 静脈高血圧症, 末梢の冷感 などがあるとされる8).われわれは，皮切創による穿刺 困難を防ぐため，できるだけ皮膚表面にまた皮切部よ り離し，静脈を表在化している，われわれは局部の浮 腫は経験しているが他の合併症は現在のところ認めて いない，人工血管による感染や，動脈表在化での動脈 瘤形成，破裂，急性動脈閉塞の危険性 ${ }^{9,10)}$ を考慮すると シャント静脈の表在化は有用なブラッドアクセスと考 えられる。

\section{結論}

表在化した静脈は，それ自体の太さ，発達不良，周 囲組織による圧迫あるいは一部の狭窄などで使用でき ないこともある。

表在化静脈の直径が一定以上すなわち，シャント造 影で $6 \mathrm{~mm}$ 以上であれば穿刺に問題はなく，術後の開 存が可能と考えられる. 術前術後に造影検查を行い, 狭窄を認めた場合，PTAなどを併用することにより 長期開存も期待できると考えられた。

本論文の要旨㹥第 46 回日本透析医学会 (2001 年, 大 阪）に扔いて発表した。

\section{文献}

1) Brescia MJ, Cimino JE, Appel $\mathrm{K}$, Hurwich $\mathrm{BJ}$ : Chronic hemodialysis using venipuncture and surgically created arterovenous fistula. N Engl J Med $275: 1089-1092,1966$

2）福田豊史, 小野利彦：動脈表在化法. 臨牀透析 $12: 69-$ 76, 1996

3）松尾賢三, 安永親生, 中本雅彦, 柳田太平, 松尾俊哉, 合屋忠信：動脈表在化の成䋶と合併症. 腎と透析 49 ： $33-42,2000$

4）酒井信治：人工血管使用のブラッドアクセス，臨牀透 析 $12: 896-906,1996$

5）久木田和丘, 米川元樹, 川村明夫：長期留置カテーテ ルの問題. 腎と透析別冊アクセス 2000, p 43-47, 2000

6）大平整爾，阿部憲司，今 忠正：ブラッドアクセスの 長期開存性および関連する危険因子。臨牀透析 12 ： 931-941, 1996

7）出月寿一, 富川伸二, 長尾 桓, 内田久則, 鮕淵康彦, 丸山雄二，多川 斉：人工血管を用いたブラッドアク セスの検討。透析会誌 27(Suppl 1)：660，1994

8）佐々木司, 東 仲宣, 田中広章 : 上腕部動静脈表在化 内シャント 26 例の検討. 腎不全外科 ‘ $97 ： 73-74,1997$

9) Ruhland D, Hussemann F: Vascular access for hemodialysis. In "Vascular Surgery" ed Heberer G, van Dongen RJAM, p 641-666, Springer Verlag, Berlin, 1989

10）小暮洋輝，佐藤直毅，田島芳雄：透析用 blood access におけるEPTFE グラフト移植および大腿動脈表在 化手術の評価と問題点. 日臨外会誌 $43 ： 191-197,1982$ 